\title{
ANALIZA CZARNYCH PROTESTÓW JAKO PRZESTRZEŃ DLA PRACY SOCJALNEJ. MASOWA MOBILIZACJA KOBIET Z PERSPEKTYWY FEMINISTYCZNEJ PRACY SOCJALNEJ
}

\begin{abstract}
Analysis of the Black Protests as a space for social work. Mass mobilisation of women from the perspective of feminist social work

The aim of the article is to look at the social mobilization of women in the Black Protests, which have been going on in Poland since 2016, as a space where women's problems were articulated. The analysis of movement from the perspective of feminist social work makes it possible to capture experiences that interweave individual problems and structural limitations on many levels of social life: citizenship, law, labour market or health.
\end{abstract}

Key words: social work, feminism social work, women's citizenship, Black Protests

\section{Wprowadzenie}

Artykuł stanowi odpowiedź na potrzebę analitycznego spojrzenia na masową mobilizację kobiet w ramach Czarnych Protestów organizowanych od 2016 roku, a także określenia ich roli w kontekście teorii i praktyki pracy socjalnej. Zaplecze teoretyczne, do którego odnosimy się w pierwszej części artykułu, stanowią przede wszystkim punkty styku klasycznych teorii pracy socjalnej z przyjętą przez nas perspektywą feministyczną. Z jej pomocą potrafimy najtrafniej opisać fenomen Czarnych Protestów, dzięki uwrażliwieniu wybranej koncepcji na kwestie dotąd pomijane przez główny nurt teoretyczny.

Współcześnie, w polskim kontekście społeczno-politycznym, wybrzmiewają głosy krytyki wobec feminizmu, sprowadzając jego rolę do ideologii niszczącej kobiecość i tradycyjną rodzinę. Z kolei postulaty ruchów kobiecych bywają traktowane jako wyabstrahowane problemy o znikomym wpływie na funkcjonowanie tkanki społecznej. Mimo uzyskania praw wyborczych, otwarcia rynku pracy czy wprowadzenia uregulowań prawnych, gwarantujących równość i wolność od dyskryminacji, dostrzec można znaczną różnicę pomiędzy teorią a rzeczywistością (Krzaklewska, Ratecka, Slany, Warat 2017). 
Jak pokazują różne opracowania, kobiety w dalszym ciągu są dyskryminowane na wielu płaszczyznach. Stopa bezrobocia wciąż pozostaje wyższa wśród kobiet ${ }^{1}$, obserwowalny jest też wzrost feminizacji ubóstwa (Charkiewicz 2010). Kobiety są nieprzerwanie narażone na przemoc seksualną, zarówno w sferze prywatnej, jak i publicznej (Piotrowska, Synakiewicz 2011). Nadal także borykają się z brakiem regulacji nieodpłatnej pracy i skutecznych rozwiązań związanych z egzekwowaniem świadczeń alimentacyjnych (Fundacja Feminoteka 2012; Chełstowska 2016). Przyjęta przez nas perspektywa feministyczna nie tylko eksponuje wspomniane problemy, ale także wtłacza w praktykę socjalną przeciwdziałanie niesprawiedliwym normom społecznym. Praca socjalna, jako zawód i dyscyplina naukowa, skupia się na kwestiach i problemach dotyczących kobiet, wśród których możemy wymienić przykładowo przemoc, ubóstwo, prawa pracownicze czy prawa reprodukcyjne (Wahab, Anderson-Nathe, Gringeri 2015). Doświadczenia kobiet mogą służyć jako soczewka w analizie społeczeństwa, w związku z czym teoretyczna część artykułu poświęcona będzie ich poszukiwaniom w założeniach i koncepcjach dyscypliny.

W drugiej części artykułu przybliżymy Czytelnikowi/Czytelniczce kontekst tworzenia się, przebieg i charakterystykę Czarnych Protestów. Zawarta w niej treść bezpośrednio odnosi się do wyników badań własnych przeprowadzonych z uczestniczkami i uczestnikami ruchu. Analiza wyników badań umożliwia dostrzeżenie wartości i problemów stojących u podstaw ruchu oraz ich powiązania z założeniami pracy socjalnej.

Wydarzenia protestacyjne, ze względu na swój interwencyjny i oddolny charakter, należy traktować jako artykulację społecznych potrzeb, dlatego powinny one zostać uwzględnione w teoretycznych ramach dyscypliny. Przedstawiono tu charakterystykę osób uczestniczących $\mathrm{w}$ protestach, a także postulaty eksponowane $\mathrm{w}$ działaniach ruchu. W części tej odniesiemy się również do zagadnienia przemian w praktykowaniu i rozumieniu obywatelstwa poprzez nieformalne sposoby zaangażowania politycznego.

\section{Specyfika pracy socjalnej}

Pojęcie pracy socjalnej, podobnie jak innych tak obszernych konstruktów, znajduje wiele różnych interpretacji. W najprostszym ujęciu to „zespół praktycznych intencji, które mają na celu poprawienie sytuacji życiowej" (Gray, Webb 2013: 9). Praktyka ta bazuje na prawnych i politycznych uwarunkowaniach danego społeczeństwa. Jej głównym celem jest wprowadzanie pozytywnych zmian w życiu ludzi.

Konceptualizując swą dziedzinę wiedzy, teoretycy i teoretyczki nie uniknęli jednak pytania o granicę pomiędzy potrzebami prywatnymi a społecznymi. Praca socjalna z tej perspektywy traktowana jest jako odpowiedź na próby pogodzenia obu sfer - wolności

1 Zob. Ministerstwo Rodziny, Pracy i Polityki Społecznej, Bezrobocie rejestrowane w Polsce. Raport miesięczny - marzec 2018; https://www.mpips.gov.pl/analizy-i-raporty/bezrobocie-rejestrowane-w-polsce/ rok-2018/ (dostęp: 10.06.2018). 
indywidualnej i solidarności społecznej (Gray, Webb 2013). Wizja ta pozostaje nie bez znaczenia dla współczesnych koncepcji teoretycznych. W centrum ich zainteresowania leżą niedobory z zakresu poczucia braterstwa, siostrzeństwa i przynależności, a także ich konsekwencje w postaci izolacji i samotności.

Naukowcy i naukowczynie stawiają pytanie o to, jak praca socjalna mogłaby wspomóc uzupełnienie tej luki. Jedną z odpowiedzi ma być zmiana perspektywy proponowana przez progresywne nurty pracy socjalnej. W ich ramach wachlarz teoretyczny poddawany jest weryfikacjom, których celem ma być opisanie danego zjawiska w sposób jak najbardziej zanurzony w szerszym społecznym kontekście. Należy zaznaczyć, że wartością, a zarazem brzemieniem pracy socjalnej jest to, że teorie wytwarzane w jej ramach w sposób ciągly wpływają na realne praktyki aktorów społecznych, to znaczy to, jaka perspektywa zostanie przyjęta, będzie rzutować na sytuację osób tak oferujących, jak i korzystających z działań pracy socjalnej (Gray, Webb 2013). Egzemplifikacją tego założenia jest kontekstualność pracy socjalnej jako teorii i praktyki. Redefinicja założeń dokonywana jest w taki sposób, by odpowiadać na pojawiające się problemy i wyzwania współczesności. W 2014 roku została przyjęta Globalna Definicja Profesji Pracy Socjalnej, w której założono, że:

\begin{abstract}
Praca socjalna jest profesją opartą na praktyce i akademicką dyscypliną, która promuje zmianę społeczną i rozwój, społeczną spójność oraz empowerment i wyzwolenie ludzi. Głównymi zasadami pracy socjalnej są prawa człowieka, wspólnotowe poczucie odpowiedzialności i poszanowanie dla różnic. Praca socjalna oparta na własnych teoriach, naukach społecznych i humanistycznych oraz na rdzennej wiedzy angażuje ludzi i struktury społeczne do występowania przeciwko życiowym trudnościom i na rzecz poprawy ludzkiego bytu².
\end{abstract}

Tym, co wydaje się najistotniejsze z perspektywy podjętego przez nas tematu, jest zwrócenie uwagi na wartości konstytuujące współczesną pracę socjalną. Odnoszą się one do podmiotowości i godności człowieka. Zdefiniowanie zasad w taki sposób umożliwia spojrzenie na problemy społeczne intersekcjonalnie, biorąc pod uwagę krzyżowanie się różnych kategorii społecznych, między innymi takich jak: płeć, orientacja seksualna, pozycja społeczna, wiek czy stopień sprawności (Howe 2011). Kategorie te, nakładając się na siebie, prowadzą do zwielokrotnionej dyskryminacji oraz wzmacniają bariery pełnego uczestnictwa w życiu społecznym.

Z kolei Anna Kola, pisząc o pracy socjalnej, zwraca uwagę na „dynamiczny” charakter tego terminu. Sposoby jego definiowania mogą się znacznie różnić w zależności od przyjętych kryteriów, jednak tym, co je łączy, jest przede wszystkim:

cel działań, jakim jest wspieranie obywateli w sytuacjach trudnych, kryzysowych czy problemowych i zachęcanie ich do podejmowania prób usamodzielnienia się i uniezależnienia (od systemu pomocy), tym samym do wyjścia z kryzysu/problemu. Sformułowanie powyższe odróżnia pracę socjalną,

2 Zob. Globalna Definicja Pracy Socjalnej; http://cdn.ifsw.org/assets/ifsw_102423-10.pdf (dostęp: 10.06.2018). 
będącą działaniem o funkcji z zasady emancypacyjnym, od opieki udzielanej osobom zależnym: chorym, w starszym wieku, dzieciom, niepełnosprawnym (Kola 2015: 137).

W opisie tym istotne jest rozróżnienie między opieką a działaniem o charakterze emancypacyjnym. Wątek ten w szczególności podejmuje wykorzystywana przez nas perspektywa feministycznej pracy socjalnej.

\section{Feministyczna praca socjalna}

Dynamika zmian społecznych, kryzys opiekuńczej polityki państwa, a także urynkowienie obszaru pomocy społecznej przyczyniły się do wyłonienia się nowych nurtów w obrębie pracy socjalnej. Wśród nich można wyróżnić także te wyraźnie kontestujące obowiązującą strukturę społeczną (Gray, Webb 2013). Wspomnieć należy przede wszystkim o krytycznej i feministycznej pracy socjalnej, które zorientowane są na podważanie hegemonicznych stosunków władzy. $U$ ich podstaw znajdują się działania nakierowane na zmianę, sprawiedliwość społeczną czy upodmiotowienie. Jednym z paradygmatów myśli krytycznej, umożliwiającej zobrazowanie podjętego przez nas tematu, jest koncepcja feministycznej pracy socjalnej, która rozwijana jest na uniwersytetach od końca lat 70 . $\mathrm{XX}$ wieku. Osoby reprezentujące ten nurt początkowo skupiały się przede wszystkim na zwróceniu uwagi na różnice wynikające z kobiecego doświadczenia, co często nie znajdowało odzwierciedlenia na poziomie teoretycznym, który był zdominowany przez uniwersalizm. Pomimo że kobiety zawsze były obecne w praktyce pracy socjalnej, zarówno jako klientki, jak i pracowniczki, to paradoksalnie płeć była niewidoczna (Hanmer, Statham 1988). Wskazywały one też na nieodpowiedni charakter praktyk, które pozycjonowały kobiety w rolach opiekunek - rodziny, dzieci, osób starszych czy osób zależnych (Dominelli 2002). Wyłonienie się nurtu feministycznego w pracy socjalnej związane jest między innymi z działalnością ruchów kobiecych. $\mathrm{U}$ jej podstaw leżą założenia różnych podejść myśli feministycznej. Odpowiedź na pytanie, czym jest ten nurt, przybliży wykaz cech wspólnych klasycznej teorii pracy socjalnej i perspektywy feministycznej.

Pierwszym spójnym elementem jest umieszczenie w centrum swego zainteresowania jednostki i jej środowiska. Feminizm problem ten rozpatruje w kategoriach publiczne- prywat ne oraz wynikających z tego podziału możliwości i ograniczeń. Miejsce kobiet uwięzionych w sferze prywatnej rozpoznawane jest jako konsekwencja patriarchalnych relacji (Young 2009). W przypadku tradycyjnej pracy socjalnej środowisko zajmuje fundamentalną pozycję w procesie kształtowania postaw i perspektyw jednostek (Wódz, Klimczak-Ziółek 2013).

Drugą kwestią wspólną dla obu podejść jest podnoszenie problemu wykluczenia społecznego. Włączają się one również w przeciwdziałanie takim praktykom. Tym jednak, co wyróżnia perspektywę feministyczną od tradycyjnej pracy socjalnej, jest zwrócenie się ku ukształtowanym strukturalnie i kulturowo procesom dyskryminacji i przemocy 
zarówno ekonomicznej, jak i seksualnej wobec kobiet, nie zaś uznanie funkcjonujących wzorów za normę (Wódz, Klimczak-Ziółek 2013).

Trzecim aspektem, podnoszonym przez oba nurty, jest walka z przemocą. Feministyczna praca socjalna zmieniła sztywne ramy tradycyjnej perspektywy, poszerzając pole widzenia problemu o sferę domową. Obszar rodziny, dotychczas pozostawiony wewnętrznym regulacjom, został poddany redefinicji ze szczególnym uwzględnieniem kwestii związanych z relacjami płci, ich normatywności, a także z wielowymiarową przemocą - zarówno fizyczną, psychiczną, jak i ekonomiczną - głównie skierowaną ku kobietom i dzieciom (Wódz, Klimczak-Ziółek 2013).

Ostatnim elementem, scalającym perspektywę tradycyjną z feministyczną, jest płeć. Osobami zarówno korzystającymi, jak i oferującymi usługi pomocowe są w przeważającej większości kobiety. Praca socjalna charakteryzuje się sytuacją, w której z jednej strony „kobietami są podopieczne, klientki, ofiary kryzysów, bezrobotne przychodzące po zasiłek, ale też ci/te «z drugiej strony»: udzielający pomocy, czyli pracownicy socjalni/ pracowniczki socjalne” (Kola 2015: 136). Z drugiej „konfrontując rzeczywistość ze światem opisanym w pracach dotyczących działań pomocowych, można zauważyć, że płeć dla pracy socjalnej nie tyle ma drugorzędne znaczenie, co raczej - nie ma go w ogóle" (Kola 2015: 136). Mechanizm ten przejawia się między innymi w braku żeńskiej formy językowej dla profesji pracownika socjalnego.

Praca socjalna i myśl feministyczna wykazują cechy wspólne. W centrum tak jednej, jak i drugiej perspektywy możemy odnaleźć wspólne cele, w tym przede wszystkim idee sprawiedliwości społecznej. Krytyka feministyczna pozwoliła uwrażliwić teorię i praktykę głównego nurtu, uwidoczniając problemy wynikające z relacji płci. Wiele tradycyjnych działań pracy socjalnej opierało się na negatywnych stereotypach dotyczących kobiet, sprowadzając je do roli żon, matek i opiekunek. Prace badaczy i badaczek wywodzących się z nurtu feministycznego doprowadziły do redefinicji szeregu problemów społecznych, zarówno tych dotyczących szerokiego grona kobiet, jak i tych, z którymi zmagają się poszczególne grupy, na przykład kobiety z niepełnosprawnościami (Dominelli, McLeod 1989). Autorka pracy Feminist Social Work, Lena Dominelli, definiuje feministyczną pracę socjalną jako:

formę praktyki, która przyjmuje doświadczenie kobiet na świecie jako punkt wyjścia do analizy i koncentrując się na powiązaniach między pozycją kobiety w społeczeństwie a jej indywidualną sytuacją, odpowiada na jej specyficzne potrzeby, tworzy relacje egalitarne w interakcjach klient-pracownik i zajmuje się nierównościami strukturalnymi. Spełnianie szczególnych potrzeb kobiet w sposób holistyczny i radzenie sobie ze złożonością ich życia - w tym z licznymi napięciami i różnorodnymi formami ucisku, które je dotykają jest integralną częścią feministycznej pracy społecznej. Skupienie się na współzależności w stosunkach społecznych gwarantuje, że zaspokaja ona również potrzeby tych, z którymi współdziałają kobiety - mężczyzn, dzieci i innych kobiet (Dominelli 2002: 7). 
W rozważaniach dotyczących feministycznej pracy socjalnej istotne jest również zwrócenie uwagi na doświadczenia kobiet, na które składają się indywidualne problemy i przecinające się z nimi strukturalne ograniczenia. Dekonstrukcja form ucisku wpływa nie tylko na sytuację kobiet, ale również całego otoczenia. Wynika to z założenia wizji feministycznych zmian, które opierają się na zrozumieniu i przekształceniu nierówności i problemów ograniczających jednostki i grupy, oraz tworzeniu egalitarnych relacji społecznych (Dominelli 2002).W centrum tak rozumianych przeobrażeń znajdują się nie tylko problemy wynikające z płci, ale również ze stopnia sprawności, wieku, orientacji seksualnej czy relacji władzy i podporządkowania. Kazimiera Wódz i Joanna Klimczak-Ziółek założenia, które stoją u podstaw feministycznej pracy socjalnej, sprowadzają do czterech głównych punktów:

1. Kobiety jako kategoria i grupa społeczna są dyskryminowane.

2. Ten stan można zmienić, bo kategoria gender jest kulturowo konstruowana.

3. Ten stan TRZEBA zmienić.

4. Mogą tego dokonać samoorganizujące się i współpracujące kobiety (Wódz, Klimczak-Ziółek 2014: 448).

Wydaje się, że odzwierciedleniem manifestu autorek są Czarne Protesty, które w swej formie i treści zarówno na poziomie indywidualnym, jak i zbiorowym przekuły wskazane obszary w praktykę społeczną. Przeprowadzone przez nas badania z uczestniczkami umożliwiły dostrzeżenie oraz wyartykułowanie poziomów i źródeł dyskryminacji kobiet, czemu poświęcona jest kolejna część artykułu.

\section{Metodologia badań}

Podstawowym celem przeprowadzonych badań było poznanie perspektyw oraz motywów uczestnictwa i zaangażowania w działania skupione wokół Czarnych Protestów. Projektując badania, zależało nam na wydobyciu indywidualnych punktów widzenia uczestniczek na ich problemy i sytuację kobiet w Polsce. Chcieliśmy dowiedzieć się również, które z postulatów podnoszonych w trakcie wydarzeń protestacyjnych były dla nich najistotniejsze i stworzyć przestrzeń do wyartykułowania tych trosk, które dotąd pozostawały głównie w sferze prywatnej.

Na materiał badawczy składa się 15 indywidualnych wywiadów pogłębionych (IDI) przeprowadzonych w maju 2016 roku, odpowiedzi na 1083 ankiety, notatki terenowe, a także treść przemówień z protestów odbywających się od 2016 roku.

W przypadku badań jakościowych próba badawcza została skonstruowana za pomocą metody kuli śnieżnej, która umożliwiła dotarcie do uczestniczek i uczestników wydarzeń protestacyjnych ze wszystkich kategorii wiekowych. Badania ilościowe były realizowane poprzez wykorzystanie kwestionariusza ankiety online. Grupę badawczą stanowiły osoby należące do grup związanych z Czarnymi Protestami w serwisie społecznościowym 
Facebook $^{3}$. Badanie zostało przeprowadzone w okresie od 3 do 10 maja 2016 roku. Po tym czasie została zablokowana możliwość wypełniania ankiety. Pomimo że badań tych nie można uznać za reprezentatywne, to jednak ich realizacja na znacznej próbie badawczej pozwala na przyjęcie pewnych uogólnień wyjaśniających i ilustrujących podjętą problematykę. Jednak należy podkreślić, że nie mają one na celu szerszej generalizacji, która to stanowi cechę badań opartych na próbie reprezentatywnej.

\section{Czarne Protesty - kontekst wyłonienia się kobiecej mobilizacji}

Tym, co ukonstytuowało ten dobrze znany w dyskursie publicznym termin, był niespotykany, masowy wyraz sprzeciwu i solidarności kobiet oraz wspierających je mężczyzn wobec próby penalizacji zabiegu aborcji w Polsce w 2016 roku. Ruch, który zatrząsł polską polityką, a także odbił się szerokim echem na całym świecie, rozpoczął się od niezorganizowanych i oddolnych działań pojedynczych osób, często niezwiązanych z organizacjami feministycznymi (Kubisa 2017). W reakcji na przyjęcie przez Sejm RP we wrześniu 2016 roku propozycji Ustawy zgłoszonej przez Instytut na rzecz Kultury Prawnej Ordo Iuris, powstała internetowa akcja polegająca na zrobieniu sobie zdjęcia i udostępnieniu go wraz z hasztagiem „czarny protest” w wybranym serwisie społecznościowym. W ciągu następnych dni w Internecie pojawiły się dziesiątki tysięcy zdjęć kobiet i mężczyzn ubranych na czarno (Majewska 2017). Do akcji włączyły się także osoby publiczne. Liczba udostępnionych zdjęć i ich zasięg medialny pokazały siłę zaangażowania kobiet. W kolejnych dniach akcja zapoczątkowana w mediach społecznościowych przeniosła się na ulice polskich miejscowości.

$\mathrm{Na}$ fali rozbudzonej mobilizacji ogłoszono 3 października 2016 roku dniem wszczęcia Ogólnopolskiego Strajku Kobiet. Wówczas osoby z ponad 150 polskich miast i wsi, a także $\mathrm{z}$ wielu miejsc na całym świecie, solidarnie wyszły na ulicę. Trzy dni później strajk osiągnął sukces - odrzucono projekt ustawy zaostrzającej dotychczas funkcjonujące prawo.

Akcje protestacyjne zmobilizowały tysiące Polek i Polaków do wspólnego działania, co nie umknęło uwadze mediów. Informacje na temat ogólnopolskich demonstracji dominowały w dyskursie medialnym. To, jak nośnym tematem okazały się Czarne Protesty, pokazują badania sondażowe przeprowadzone przez CBOS w listopadzie 2016 roku. Jak wynika z przedstawionego przez fundację raportu, o Czarnych Protestach słyszeli prawie wszyscy, niezależnie od płci, miejsca zamieszkania czy poglądów politycznych (CBOS 2016): 64\% kobiet i 52\% mężczyzn zadeklarowało zainteresowanie protestami, które

3 Były to grupy, które w nazwie posiadały odniesienia do miast: Biała Podlaska, Częstochowa, Grudziądz, Jędrzejów, Kłodzko, Kraków, Łódź, Nowy Sącz, Olsztyn, Szczecin, Tarnów, Toruń, Warszawa, Zagłębie, Zawiercie, Zgorzelec; regionów: śląskie i lubelskie; oraz grupy tematyczne, takie jak: „Grupa główna”, „PETYCJA - strajk kobiet trwa”, „Czarny Protest i kobieta: perspektywa chrześcijańsko-humanistyczna”, „Ogólnopolski Strajk Kobiet UW - grupa dyskusyjno-organizacyjna”, „Ogólnopolski Strajk Kobiet Offtopowo”, „Ogólnopolski Strajk Kobiet - ART”. 
przejawiało się między innymi śledzeniem relacji na ich temat. W raporcie poruszono także kwestię podejmowanych form zaangażowania, wśród których najczęstszym było ubranie się na czarno (12\%), również w geście solidarności przez osoby niebiorące bezpośredniego udziału w demonstracji (CBOS 2016).

Mówiąc o Czarnych Protestach, nie należy pomijać szeregu innych wydarzeń bazujących na potencjale mobilizacyjnym zgromadzonym w trakcie pierwszych działań ruchu. Wspomnieć można przede wszystkim o Międzynarodowym Strajku Kobiet zorganizowanym 8 marca 2017 roku. Doszło wówczas do wielkiej akcji skupiającej uwagę ponadnarodowej opinii publicznej na wielość problemów kobiet. Akty solidarności płynące $\mathrm{z}$ całego świata, a także polityczny sukces, jaki osiągnął ruch, pobudziły niespotykane dotąd poczucie sprawstwa i gotowości do współdziałania. Jak pokazał rok 2018, wytworzony potencjał mobilizacyjny wciąż przekuwa się w walkę w imię praw kobiet. Czarne Protesty należy traktować jako ruch społeczny, którego uczestniczki wciąż podejmują różnorakie działania. Przykładem tego jest między innymi „Czarny Piątek”, który miał miejsce 23 marca 2018 roku. W odpowiedzi na kolejną próbę ograniczenia praw zawartych w dotychczas obowiązującej ustawie o planowaniu rodziny, ochronie płodu ludzkiego i warunkach dopuszczalności przerywania ciąży ulicami Warszawy solidarne przeszło prawie 60 tysięcy osób (Kubisa 2018).

Mobilizacja społeczna w ramach Czarnych Protestów miała bezprecedensowy charakter w najnowszej historii Polski. Po raz pierwszy w walkę zaangażowała się tak wielka liczba osób. Poziom uczestnictwa w takich formach obywatelskiej partycypacji jak demonstracja czy strajk był najwyższy od 28 lat (CBOS 2017). By odkryć fenomen opisywanego przez nas zjawiska, warto przybliżyć profil osób protestujących.

\section{Charakterystyka uczestniczek i uczestników}

Na podstawie przeprowadzonych badań można zaobserwować, że jednym z największych sukcesów Czarnych Protestów było zaangażowanie osób, które wcześniej nie włączały się w działania na rzecz praw kobiet oraz nie funkcjonowały w formalnych strukturach społeczeństwa obywatelskiego. 57\% badanych osób przed Ogólnopolskim Strajkiem Kobiet nie podejmowało działań w trosce o prawa kobiet, znaczna większość z nich (67\%) nie była również członkinią lub członkiem żadnej organizacji pozarządowej. Manify, które odbywały się w wielu polskich miejscowościach na początku marca każdego roku, znacznie wcześniej zwracały uwagę na problemy wynikające z dotychczas obowiązującej ustawy regulującej prawo reprodukcyjne oraz na dyskryminację kobiet funkcjonującą na wielu płaszczyznach życia społecznego. Nigdy jednak wydarzenie to nie zdobyło wielkiej popularności. Okazało się, że wyłoniony ruch wytworzył przestrzeń do działania dla zupełnie nowych osób. 


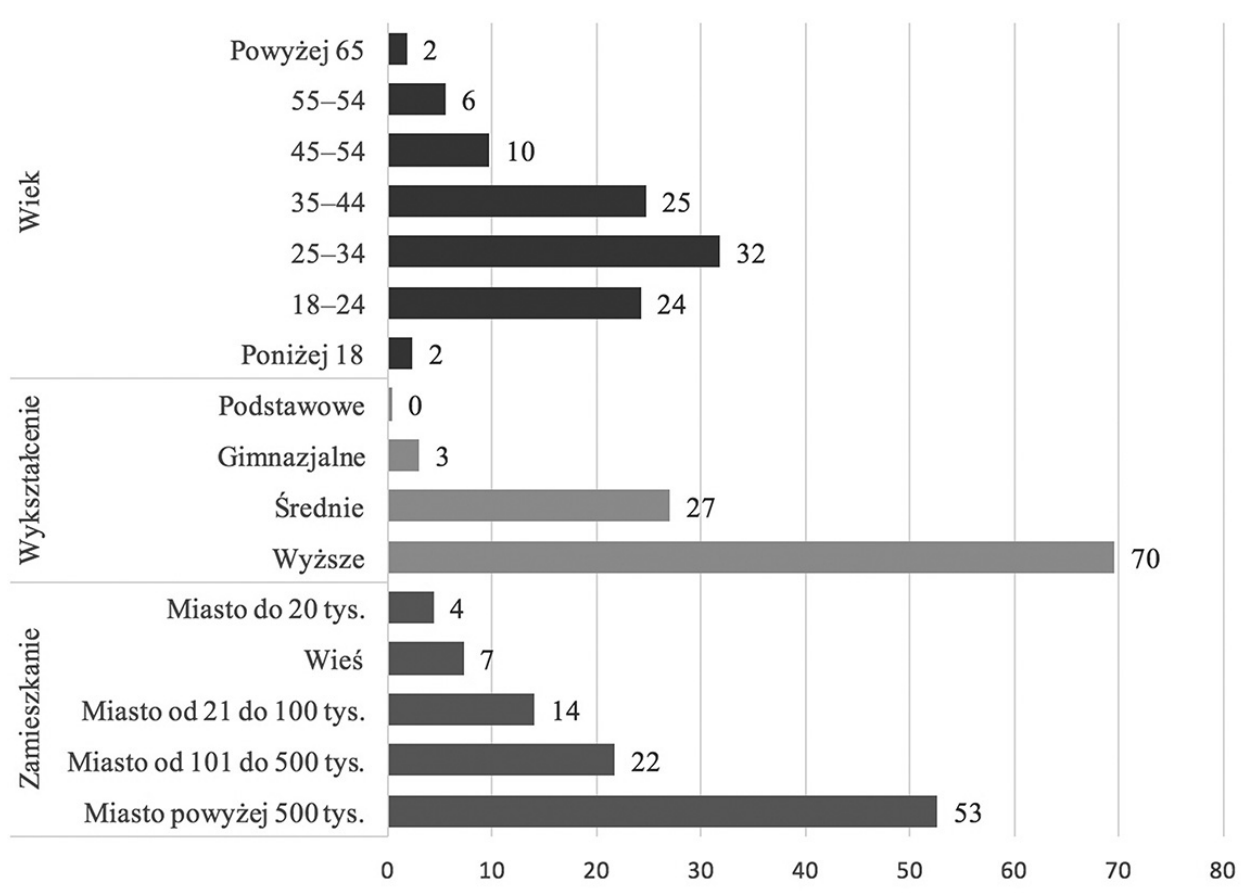

Wykres 1. Profil badanych ( $\mathrm{N}=1083$, dane $\mathrm{w} \%)$

Źródło: Opracowanie własne.

Czarne Protesty stały się przyczyną zawiązania wielu grup lokalnych, a także tematycznych (np. Czarny Protest i kobieta: perspektywa chrześcijańsko-humanistyczna ${ }^{4}$ ) w serwisie Facebook. Początkowo powstały w celu organizacji i informowania o wydarzeniach protestacyjnych, jednak z upływem czasu stały się przestrzenią dyskusji i wymiany myśli między użytkowniczkami. Problemy poruszane w grupach odnosiły się do całego spektrum kobiecych doświadczeń. Wymieniano się uwagami dotyczącymi lekarzy i lekarek, a także aptek, zwracając uwagę na problemy wynikające z tak zwanej klauzuli sumienia. Wśród innych poruszanych problemów znajdowała między innymi krytyka poziomu edukacji seksualnej. Niektóre z grup przybrały postać samopomocowych, poprzez kontakty międzynarodowe organizowano między innymi zapasy antykoncepcji awaryjnej, do której legalny dostęp został ograniczony ${ }^{5}$.

W przeprowadzonych przez nas badaniach ilościowych zdecydowaną większość osób stanowiły kobiety (97\%). Najczęściej były to osoby mieszkające w dużych miastach

4 Zob. strona grupy w serwisie Facebook; https://www.facebook.com/groups/1496352113714930/ (dostęp: 10.05.2018).

5 Zob. https://www.womenonweb.org/ (dostęp: 10.06.2018). 
powyżej 500 tysięcy mieszkańców i mieszkanek (53\%) oraz średnich - od 101 do 500 tysięcy mieszkańców (22\%). Wśród osób protestujących największy odsetek stanowiły osoby z wyższym (70\%) lub średnim (27\%) wykształceniem. W przypadku wieku co trzecia badana osoba była pomiędzy 25. a 34. rokiem życia (32\%). Z kolei osoby młodsze (18-24) oraz starsze (35-44) stanowiły odpowiednio 24 i $25 \%$. Najmniej licznie reprezentowanymi grupami ze względu na wiek były osoby najmłodsze - do 18 lat, oraz najstarsze - powyżej 65. roku życia (2\%).

Na podstawie przytoczonych wyników badań można zaobserwować, że mimo bezprecedensowej liczby osób zaangażowanych w działania protestacyjne, osoby te nie stanowią grupy silnie zróżnicowanej społecznie. Jednak badania pokazują, że siła solidarności leżąca u podstaw Czarnych Protestów polegała na publicznym demonstrowaniu nie tylko we własnej sprawie, co zostanie przybliżone w kolejnej części.

\section{Czarne Protesty - czy tylko problem dostępu do aborcji?}

W dalszej kolejności należałoby zwrócić uwagę na problemy kobiet oraz postulaty, które zostały uwidocznione w działaniach ruchu od 2016 roku. Pierwszy Czarny Protest, jako rezultat próby ograniczenia dotychczasowej ustawy regulującej prawo do aborcji, skupiał się w głównej mierze na powstrzymaniu legislacji projektu. Wybrzmiewające głosy aprobowały utrzymanie „kompromisu aborcyjnego”. Badane osoby zwróciły uwagę, że protest przyczynił się także do nagłośnienia wielu innych problemów:

(...) sam strajk był dla mnie o dostęp do aborcji, ale poruszył wiele wątków, na które nie ma na co dzień miejsca, a które - jak się okazało - siedzą kobietom w głowach. Edukacja seksualna, równość płci - i pokazał, że to nie jest coś, co jest Polkom obojętne (Kobieta 30).

Taki protest ma walory edukacyjne, ludzie dowiadują się, że taki problem jest, że coś się ludziom nie podoba, więc może warto się zastanowić. Podczas protestu ludzie rozmawiali z sobą (Mężczyzna 57).

W krótkim czasie doszło do rozszerzenia zapisanych postulatów. Co więcej, w trakcie demonstracji, spotkań i dyskusji organizowanych wokół zagadnień kobiecych otwarta przestrzeń sprawiła, że kobiety często po raz pierwszy występowały publicznie. Osoby przemawiające odnosiły się do różnych doświadczeń, tożsamości i problemów kobiet.

Na podstawie przeprowadzonych badań możemy wskazać najczęściej wybierane postulaty. Odpowiedzi na to pytanie w kwestionariuszu ankiety były odzwierciedleniem żądań promowanych przy okazji Międzynarodowego Strajku Kobiet ${ }^{6}$. Jak się okazuje, dostęp do bezpiecznego przerywania ciąży był najczęściej wybieraną odpowiedzią wśród osób ze wszystkich kategorii wiekowych (57\%). Wyjątek stanowiły jedynie osoby

${ }^{6}$ Pytanie w kwestionariuszu ankiety brzmiało: Poniżej znajdują się postulaty Międzynarodowego Strajku Kobiet w Polsce z 8.03.2017 roku. Jakie są dla Pana/i TRZY najważniejsze postulaty? 
pomiędzy 55. a 64. rokiem życia, które częściej wskazywały na dostęp do nowoczesnej bezpłatnej antykoncepcji i zabiegów sterylizacji. W przypadku tej grupy dostęp do aborcji znajdował się na drugim miejscu. Drugim w kolejności zagadnieniem wśród ogółu badanych była rzetelna edukacja seksualna (39\%). Kolejnymi najczęściej wybieranymi postulatami przez badanych były: dostęp do nowoczesnej bezpłatnej antykoncepcji i zabiegów sterylizacji (36\%), utrzymanie standardów opieki okołoporodowej (26\%) oraz likwidacja tak zwanej klauzuli sumienia (21\%).

Odpowiedzi na pytania otwarte w kwestionariuszu ankiety oraz pozostawione do niej komentarze umożliwiły dostrzeżenie wielości istotnych problemów dla kobiet. Wiele uwag wskazywało, że wszystkie lub większość postulatów są istotne w takim samym stopniu, a wybranie zaledwie trzech dla nich najważniejszych okazało się niezwykle trudne dla badanych. Jak odpowiedziała jedna z osób:

Wybranie trzech najważniejszych postulatów Strajku Kobiet: wszystkie są dla mnie równie ważne
i nie umiałam wybrać „najważniejszych”. Zaznaczyłam te, które według mnie najbardziej wpływają na
codzienne życie kobiet, a których nieprzestrzeganie najbardziej i najszybciej odbije się negatywnie na
zdrowiu i życiu kobiet oraz ich dzieci. Brak możliwości decydowania o własnym ciele (a w skrajnych
przypadkach i życiu) uważam za barbarzyńskie i uwłaczające ludzkiej godności (Kobieta 26).

Odwoływanie się do godności ludzkiej pojawiało się zarówno w odpowiedziach respondentek, jak i wybrzmiewało głośno w przemówieniach uczestniczek demonstracji. Często pojawiały się również odniesienia do praw człowieka, do których bezpośrednio odwołuje się przytoczona wcześniej Globalna Definicja Profesji Pracy Socjalnej. Na protestach w przestrzeni publicznej skandowano hasło: „Prawa kobiet - prawami człowieka”. Pojawiało się ono także na transparentach. Innym popularnym odwołaniem do praw podstawowych byly prawa obywatelskie:

Ciężko wybrać tylko trzy postulaty Strajku Kobiet, bo równie ważne są standardy okołoporodowe, edukacja, antykoncepcja, badania prenatalne, prawo do przerywania ciąży, religia w parafii, a nie szkole, bo to wszystko są prawa obywatelskie w świeckim kraju. To podstawy, więc ciężko dyskutować, co jest ważniejszą podstawą (Kobieta 47).

Obywatelstwo kobiet i sposoby jego praktykowania są kolejnymi istotnymi zagadnieniami w kontekście Czarnych Protestów. Po raz pierwszy w historii współczesnej Polski kobiety w takim stopniu były zaangażowane w działania obywatelskie. Trwający od kwietnia 2016 roku spór pomiędzy kobietami a zinstytucjonalizowaną formą polityki doprowadził do wytworzenia się nowych oddolnych inicjatyw, organizacji czy grup tworzących przestrzeń dyskusji i wspólnego działania na rzecz uznania kobiet i ich problemów. Wydarzenia protestacyjne to czas, w którym kobiety zaczęły dostrzegać i budować świadomość polityczną poprzez doświadczenie własnej skuteczności i skali mobilizacji (Kowalska, Nawojski, Pluta 2018). Było to widoczne w trakcie demonstracji, kiedy to kolejne osoby spontaniczne zabierały głos (często zaznaczając, że jest to ich 
pierwsze publiczne przemówienie), mówiąc o swoich doświadczeniach, problemach i strachu, ale także o poczuciu wspólnej sprawczości i siły solidarności. Miało to swoje odbicie w rozmowach $\mathrm{z}$ uczestniczkami:

Chciałam, żeby politycy zobaczyli rozmach i naszą solidarność. Oczekiwałam, że wezmą pod uwagę to, że się jednoczymy i że nie warto podejmować bez nas decyzji (Kobieta 22).

Myślę, że poczułam się silniejszą kobietą, kobietą, która potrafi walczyć o swoje prawa. Poczułam się zjednoczona $\mathrm{z}$ innymi kobietami i to było naprawdę fajne doświadczenie (Kobieta 23).

Widać było moc tych kobiet, jak jechałam tramwajem, patrzyłam, ile osób jest ubranych na czarno, i czułam taką wspólnotę. Uśmiechaliśmy się do siebie sympatycznie (...). Wracając, czułam taką jedność, że te kobiety miały wreszcie coś do powiedzenia (Kobieta 61).

Spojrzenie na Czarne Protesty z perspektywy obywatelstwa przyczynia się do jego redefinicji, polegającej na włączaniu kobiet $\mathrm{w}$ praktykowanie obywatelstwa $\mathrm{z}$ całym bagażem ich doświadczeń, „chodzi o rekonstrukcję pojęcia obywatelstwa ujętego w języku wartości kojarzonych z kobiecymi rolami karmicielek, opiekunek, obrończyń rodziny zarówno jako całości, jak i poszczególnych jej członków” (Werbner 2007: 94). Działania w ramach Czarnych Protestów od samego początku były skupione wokół problemów wynikających z różnych tożsamości kobiet. Uczestniczki odnosiły się do swojego własnego doświadczenia, także tego bazującego na roli matki, która w polskim dyskursie jest niezwykle silna (Hryciuk 2012).

Na podstawie badań możemy zaobserwować dwa podejścia do włączania roli matki w praktykowanie obywatelstwa. Z jednej strony są to wyobrażenia siebie jako przyszłej matki:

Nie wyobrażam sobie, jako przyszła matka, aby moje dziecko nie miało specjalistycznej opieki od poczęcia. Chcę mieć pewność, że jest otoczone opieką i wszystko jest w porządku. Z drugiej strony, gdyby moje dziecko miało urodzić się ciężko chore, cierpieć lub żyć zaledwie kilka godzin w bólu, chciałabym mieć możliwość wyboru. Nie pozwolę, żeby moje dziecko cierpiało (Kobieta 26).

Z drugiej są to doświadczenia związane bezpośrednio z praktykowaniem roli matki i działaniem politycznym w imieniu swoich dzieci:

Jestem mamą już prawie 11-letniej dziewczynki. Córa miała po porodzie sepsę, więc w pełni rozumiem, czym jest borykanie się z chorobą dziecka, tym bardziej wiem, jak cierpiały matki dzieci z wadami wrodzonymi, które miałam okazję poznać podczas rehabilitacji. Obecnie córka ma zaburzenia transmisji nerwowo-mięśniowej, na stałe bierze mestinon. Nie wiadomo, czy będzie mogła być w ciąży, czy ciąża nie będzie zagrażać jej życiu i czy ewentualnie jej dziecko urodzi się zdrowe. Dlatego byłam na proteście. Dostęp do edukacji seksualnej jest niezbędny. Moja córka już wie, jak kobieta zachodzi w ciążę i wie, co robić, by w ciążę nie zajść (Kobieta 35). 
Pomimo że według badań uczestniczki protestów nie stanowiły grupy bardzo zróżnicowanej społecznie, to jednak możemy dostrzec, iż uczestnictwo w Czarnych Protestach było postrzegane jako walka nie tylko we własnym, lecz także w imieniu innych kobiet. W przemówieniach niejednokrotnie wybrzmiało doświadczenie solidarności i jedności ponad podziałami:

Martwię się i jestem tu dla wszystkich kobiet, których tu z nami nie ma. Bo pracują właśnie na drugiej zmianie, bo mieszkają za daleko od miasta, bo nie interesują się polityką, bo nie miały z kim zostawić dziecka czy starszej osoby, którą się opiekują, bo żyją w bańce, w której o takich jak my mówi się, że jesteśmy szmatami i dziwkami, bo żyją z niepełnosprawnością, która zatrzymała je w domu, czy mają męża, który grozi, że spuści jej łomot, jak wyjdzie na miasto. To głównie dla nich musimy solidarnie walczyć! (Kobieta 23.03.2018).

W trakcie działań w przestrzeni publicznej wybrzmiały doświadczenia i problemy, które wynikają nie tylko z płci, ale także z innych nakładających się na siebie kategorii społecznych. Jednym z tych problemów, które uwidoczniły Czarne Protesty, były trudności i bariery stojące przed kobietami z niepełnosprawnościami. Przemawiająca na krakowskim Rynku kobieta zwróciła uwagę, że:

Jest tutaj z nami pewnie niewiele kobiet z niepełnosprawnościami. Dlaczego? Między innymi dlatego, że większość z nas napotyka bariery, które często uniemożliwiają uczestnictwo w życiu społecznym. Przeważnie jesteśmy niewidoczne. Dla rządzących kwestia naszych praw reprodukcyjnych czy w ogóle życia seksualnego nie istnieje. Jeżeli już się o nas mówi, to jako o odbiorczyniach pomocy. Traktuje się nas w paternalistyczny sposób i upupia. Część z nas segreguje się w szkołach specjalnych, domach pomocy społecznej, szpitalach psychiatrycznych, czy ubezwłasnowolnia. Nasze problemy traktuje się jako mniej ważne i marginalizuje. Prawie nigdy nie mamy możliwości wypowiadać się we własnym imieniu czy na tematy ogólnospołeczne. A przecież my jesteśmy! Mamy prawa i poglądy! Chcemy, żebyście nas w końcu usłyszeli i usłyszały (Kobieta 23.03.2018).

Wyeksponowała ona w swoim przemówieniu, wydaje się, podstawowe problemy kobiet, które w połączeniu z niepełnosprawnościami wzmacniają poczucie dyskryminacji i uprzedmiotowienia:

W Polsce w ramach publicznej służby zdrowia praktycznie nie ma gabinetów, gdzie kobieta $\mathrm{z}$ niepełnosprawnością ruchu mogłaby samodzielnie lub z minimalnym wsparciem skorzystać z fotela ginekologicznego. Skutkuje to na przykład sytuacją, w której pacjentkę wnoszą na fotel pracownicy remontujący budynek. Chcemy zindywidualizowanego wsparcia, które umożliwi nam korzystanie z prawa do macierzyństwa, w tym do opieki przed- i okołoporodowej. Chcemy zapewnienia wszystkich innych dostępnych kobietom świadczeń związanych z macierzyństwem (Kobieta 23.03.2018). 
Przez pryzmat doświadczeń uczestniczek Czarnych Protestów możemy dostrzec indywidualne problemy, które w połączeniu ze strukturalnymi barierami ograniczają możliwości pełnego partycypowania kobiet w życiu społecznym. Jednym z ograniczeń skutecznie utrudniającym kobietom pełne praktykowanie obywatelstwa jest nieodpłatna praca opiekuńcza. Ten sposób pracy kobiet w domach nie został dotychczas uznany ani w obowiązkach obywatelskich, ani też nie otwiera możliwości dostępu do pełnych praw socjalnych. $Z$ tej perspektywy brak zapewnienia na przykład publicznej opieki nad dziećmi czy nierówności ekonomiczne mogą stanowić istotne bariery uniemożliwiające pełne zaangażowanie w życie społeczne i obywatelskie (Ciaputa 2016).

\section{Podsumowanie}

Badania i obserwacja Czarnych Protestów umożliwiają uchwycenie kobiecych problemów, doświadczeń czy tożsamości, które wydaje się, że po raz pierwszy zaistniały w tak znacznym stopniu w przestrzeni publicznej. Zryw społeczny, który powstał w kontekście próby ograniczenia dotychczasowej Ustawy o planowaniu rodziny, ochronie płodu ludzkiego i warunkach dopuszczalności przerywania ciąży, stanowił jedynie impuls do kobiecego zaangażowania społecznego. Przestrzeń, która została wytworzona w trakcie działań ruchu, umożliwiła wybrzmienie głosów dotąd nieobecnych w dyskursie publicznym i medialnym. Fakt ten ma nieocenione znaczenie, biorąc pod uwagę ogromną tabuizację tematu aborcji w Polsce. Dotychczas panująca norma zdaje się jednak nieustannie ulegać sile wspólnoty doświadczeń wytworzonej w trakcie wydarzeń protestacyjnych. Przykładem tego może być między innymi oddolna akcja „Nie jesteś sama -billboard aborcyjny"7. Czarne Protesty należy traktować jako oddolny ruch społeczny walczący o upodmiotowienie obywatelskie kobiet i uznania ich problemów. Argumentując istotność dostrzeżenia Czarnych Protestów w perspektywie działań pracy socjalnej, odwołamy się do słów Rafała Drozdowskiego (2016: 237), który w tekście Praca socjalna w zmieniającym się społeczeństwie pisze:

\footnotetext{
Wydaje mi się, że jednym z głównych celów pracy socjalnej powinno stać się wspieranie wszystkich możliwych przejawów demokracji obywatelskiej, poszerzanie (a niekiedy odzyskiwanie) przestrzeni, w obrębie których jej procedury i narzędzia służą nie tylko zwiększaniu poczucia podmiotowości, lecz także rozwiązywaniu konfliktów. Wydaje mi się wreszcie, że praca socjalna powinna intensywnie promować i pomagać urzeczywistniać ideę społeczeństwa kolaboratoryjnego, w którym doświadczenia i wiedza żadnej zbiorowości nie są z góry dyskwalifikowane i które jest z założenia otwarte nie tylko na współpracę mimo różnic, ale i na współpracę inspirowaną różnicami.
}

7 Była to oddolna inicjatywa grupy aktywistek walczących z alienacją i brakiem zrozumienia społecznego w stosunku do kobiet dokonujących zabiegu aborcji. Akcja polegała na zebraniu funduszy za pośrednictwem internetowej zbiórki na produkcję plakatów, a następnie wynajęciu przestrzeni na billboardy. $\mathrm{Na}$ plakatach umieszczony był napis: „Statystycznie 1 z 3 Twoich znajomych miała aborcję. Nie jesteś sama”. 
Na podstawie naszych badań i obserwacji uważamy, że Czarne Protesty należy rozpatrywać znacznie szerzej aniżeli w kontekście dostępu do aborcji. W trakcie podejmowanych działań protestacyjnych doszło do wyartykułowania trosk bezpośrednio od osób zaangażowanych. Przez ich pryzmat możemy dostrzec cały kalejdoskop problemów kobiet, które w końcu mogły zaistnieć w dyskursie publicznym. Spojrzenie na nie z perspektywy feministycznej pracy socjalnej umożliwia uchwycenie kobiecego doświadczenia, które przeplata indywidualne problemy jednostkowe i strukturalne ograniczenia na wielu płaszczyznach życia społecznego: edukacji, prawa, rynku pracy czy zdrowia. Sprzeciw kobiet uwidocznił obszary, które uniemożliwiają im pełne włączenie się i aktywność w życiu społecznym. Praca socjalna, kładąc nacisk na wzmacnianie sprawczości społecznej wykluczonych grup, musi brać pod uwagę problemy i ograniczenia w zakresie praktykowania obywatelstwa przez kobiety, niedobory ich reprezentacji politycznej, bariery w dostępie do formalnej polityki, a także konsekwencje wynikające z nakładających się kategorii społecznych, takich jak płeć, wiek, orientacja seksualna czy stopień sprawności.

\section{Bibliografia}

CBOS - Polacy o prawach kobiet, „czarnych protestach” i prawie aborcyjnym. Komunikat z badań nr 165/2016 (2016). CBOS, Warszawa.

CBOS - Aktywności i doświadczenia Polaków w 2016 roku, Komunikat z badań nr 12/2017 (2017). CBOS, Warszawa.

Charkiewicz E. (2010). Kobiety i ubóstwo. Widzialna ręka neoliberalnego państwa, w: Raport Think Tanku Feministycznego 4/2012, Kobiety i ubóstwo w Polsce. Badania i analizy 2008-2011; http://www.ekologiasztuka.pl/pdf/kobiety_ubostwo_raport TTF.pdf (dostęp: 25.04.2017).

Chełstowska A. (2016). Alimenty na dzieci - diagnoza polskiego systemu i przeglad praktyk zagranicznych. Instytut Spraw Publicznych, Warszawa; https://www.rpo.gov.pl/sites/default/ files/Agata\%20Che\%C5\%82stowska\%20Alimenty\%20-\%20diagnoza.\%20Raport\%20ISP. pdf (dostęp: 25.04.2017).

Ciaputa E., Kowalska B., Krzaklewska E. et al. (2016). Równość ptci i jakość życia. Raport z badań sondażowych. Uniwersytet Jagielloński, Kraków.

Dominelli L. (2002). Feminist Social Work Theory and Practice. Palgrave, Basingstoke.

Dominelli L., McLeod E. (1989). Feminist Social Work. Macmillan, Basingstoke.

Drozdowski R. (2016). Praca socjalna w zmieniającym się społeczeństwie. „Ruch Prawniczy, Ekonomiczny i Socjologiczny", 3: 231-238.

Dryjańska A. et al. (2013). Różowa strefa gospodarki. Nieodpłatna praca kobiet. Fundacja Feminoteka Warszawa; https://issuu.com/boell/docs/raport_rozowa_strefa_gospodarki (dostęp: 25.04.2017).

Fundacja Feminoteka (2012). http://feminoteka.pl/raporty/ (dostęp: 10.06.2018)

Globalna Definicja Pracy Socjalnej; http://cdn.ifsw.org/assets/ifsw_102423-10.pdf (dostęp: 10.06.2018). 
Gray M., Webb S.A. (2013). Praca socjalna. Teorie i metody. Podręcznik akademicki, tłum. B. Maliszewska. Wydawnictwo Naukowe PWN, Warszawa.

Howe D. (2011). Krótkie wprowadzenie do teorii pracy socjalnej, tłum. P. Matela. Instytut Rozwoju Służb Społecznych, Warszawa.

Hryciuk R. (2012). O znikającej matce. Upolitycznione macierzyństwo w Polsce i Ameryce Łacińskiej, w: R. Hryciuk, E. Korolczuk (red.), Pożegnanie z Matka Polka? Dyskursy, praktyki i reprezentacje macierzyństwa we współczesnej Polsce. Wydawnictwa Uniwersytetu Warszawskiego, Warszawa.

Kola A. (2015). Odkryć ukryte... Praca socjalna w Polsce z perspektywy women's/gender/feminist studies. „AVANT”, VI, 1: 136-153.

Kowalska B., Nawojski R., Pluta M. (2018). Kobiece rewolucje wciąż trwają, w druku.

Krzaklewska E., Ratecka A., Slany K., Warat M. (2017). Gender Equality and Quality of Life: Perspectives from Poland and Norway. Peter Lang, Frankfurt am Main.

Kubisa J. (2017). Obrona praw reprodukcyjnych $w$ Polsce. „Globalny Dialog”, 1: 30-31.

Kubisa J. (2018). Ufajmy kobietom; http://krytykapolityczna.pl/kraj/julia-kubisa-czarny-piatek-ufajmy-kobietom/ (dostęp: 10.06.2018).

Majewska E. (2017). Tramwaj zwany uznaniem: feminizm i solidarność po neoliberalizmie. Instytut Wydawniczy Książka i Prasa, Warszawa.

Ministerstwo Rodziny, Pracy i Polityki Społecznej (2018). Bezrobocie rejestrowane w Polsce. Raport miesięczny - marzec 2018; https://www.mpips.gov.pl/analizy-i-raporty/bezrobocie-rejestrowane-w-polsce/rok-2018/ (dostęp: 10.06.2018).

Piotrowska J., Synakiewcz A. (2011). Dość milczenia. Przemoc seksualna wobec kobiet i problem gwałtu $w$ Polsce. Fundacja Feminoteka, Warszawa; https://pl.boell.org/sites/default/files/ dosc_milczenia._przemoc_seksualna_wobec_kobiet_1.pdf (dostęp: 25.04.2017).

Wahab S., Anderson-Nathe B., Gringeri C.E. (red.) (2015). Feminisms in Social Work Research: Promise and Possibilities for Justice-Based Knowledge. Routledge, Nowy Jork.

Werbner P. (2007). Upolitycznione macierzyństwo i feminizacja obywatelstwa: ruchy kobiece i transformacja sfery publicznej, w: R.E. Hryciuk, A. Kościańska (red.), Gender. Perspektywa antropologiczna, t. 1: Organizacja społeczna. Wydawnictwa Uniwersytetu Warszawskiego, Warszawa.

Wódz K., Klimczak-Ziółek J. (2014). Feministyczna perspektywa (w) pracy socjalnej, w: A. Kotlarska-Michalska (red.), Kobiety w pracy socjalnej. Wydawnictwo Uniwersytetu Adama Mickiewicza, Poznań.

Young I.M. (2009). Bezstronność i obywatelska sfera publiczna. Niektóre implikacje feministycznej krytyki teorii moralnej i politycznej, tłum. J. Maciejczyk, Biblioteka Online Think Tanku Feministycznego. 